\title{
ESTUDO DA SENSIBILIDADE DE UM SISTEMA BIOLÓGICO EMPREGADO NO DIAGNÓSTICO DA RAIVA
}

VALDSON DE ANGELIS CORTES

Dissertação de Mestrado apresentada à Faculdade de Saúde Pública da Universidade de São Paulo, Departamento de Prática de Saúde Pública, para obtenção do título de Mestre em Saúde Pública.

Orientador: Prof. Dr. Gil Vianna Paim 
$\AA$

memōr ia

de

meus

pais. 
Ao

Prof.Dr. Gil Vianna Paim

pela orientação do presente trabalho. 


\section{A GRA D E E I M E N T O S}

A Chefia do Departamento de Medicina Veterinā ria Preventiva e Saũde Animal da Faculdade de Medicina Vetorí nária e Zootecnia da Universidade de são Paulo, constituida pẹ los Drs. Omar Jaques Marzagão Barbuto e Josē de Angelis Côrtes, que nos cedeu gentilmente o laboratório dessa Entidade para a realização do experimento e demais funcionários pela prestimo sa colaboração.

Aos Drs. Moacir Rossi Nilsson, Silvio Arruda Vasconcellos, Fumio Honma Ito e Cezar Eduardo Enriquez Rozas, pela valiosa colaboração prestada durantc a execução deste trą balko.

Ao Diretor do Instituto Pasteur de são Pallio, Dr. Murilo Pacca de Azevedo e as Dras. Luiza Terezinha Madia de Souza Morita e Esther Luiza Bocato Camelet e dcmais funcio nários pelas facilidades que nos propiciaram para a colheita das amostras.

Ao Diretor do Centro de Controle de Zoonoses de São Paulo, Dr. Arnaldo Vila Nova e demais funcionários pe las faciliajes que nos proporcionaram na fase de colheita das amostras.

A Bibliotecária Daisy Pires Noronha, da Faculdade de Saúde Püblica da Universidade de São paulo, pela valio sa colaboração prestada na revisão das referências bibliogräfi cas. 
pg.

1. INTRODUÇÃO $\ldots \ldots \ldots \ldots \ldots \ldots \ldots \ldots \ldots \ldots \ldots \ldots \ldots \ldots \ldots \ldots \ldots$

2. MATERJAL E METOdOS....................... 6

2.1. Secreção salivar..................... 6

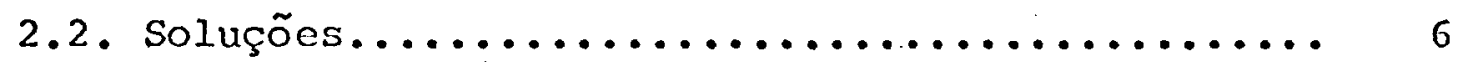

2.2.1. Cloridrato de pilocarpina........... 6

2.2 .2 . Diluente...................... 6

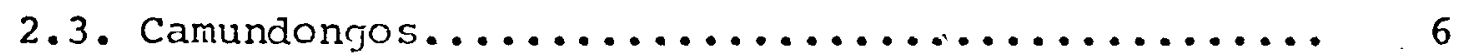

2.4. Colheita das amostras................... 6

2.5. Identificação do virus................... 7

3. RESULTADOS............................. 8

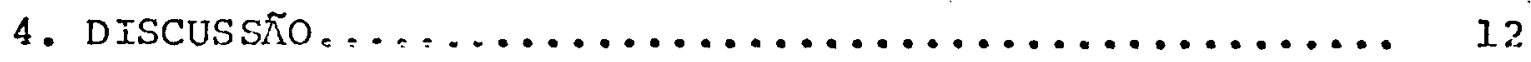

5. Conchusõrs............................. 14

6. REFERENCIAS BIBLIOGRAFICAS................. 15 
Quarenta e duas amostras de saliva de cães raivo sos foram examinadas por inoculação intracerebral, para apre ciar a sensibilidade do camundongo lactente em relação a do adulto jovem, no diagnóstico da raiva. O isolamento do vỉus rábico de 100\% das amostras utilizadas, nos dois sistemas biológicos, mostrou uma certa concordância dos resultauos ob tidos.

A identificação de inclusões celulares e de antî. geno rābico, mediante as técnicas de seliers e de anticorpos fluorescontes, revelou uma perfeita regularidade desses ind cadores da infecção rábica nas impressões encefálicas tanto de camundongos lactentes como de adultos jovens.

- camundongo lactente revelou una certa superio ridade para revelar inclusões celulares e antígeno rábico, par ticularmente à imunofluorescēncia ãireta.

A taxa de mortalidade mais elevada observada nos grupos de camundongos lactentes, revelou uma diferença alta mente significante em relação ao mesmo evento verificado nos grupos de camundongos adultos jovens, evidenciando uma mais baixa resistência do camundongo lactente ao vỉrus rābico. 
SUM M A R Y

42 saliva samples of rabid dogs were examined by intracerebral inoculation to apreciate the sensibility of suckling mouse in relation to the young adult in the diagno sis of rabies. Rabies virus isolation of all of the samples utilized in the two biological sistems showed certain agree ment of results.

Identification of cellular inclusions and rabies antigen by means of the technics of Sellers and fluorescent antibodies revealed a perfect regularity of these indicators of the rabies. infection in the encephalic impressions of suck ling mice and young adults.

Suckling mouse were somewhat superior to reveal cellular inclusions and rabies antigen especially on direct inmunofluorescence.

The higher death rate observed in the suckling mice groups was highly significant in relation to the same event verified in the young adult mice groups demonstrating a lower resistance of suckling mouse to rabies virus. 


\section{INTRODUCR̃O.}

A raiva é uma das antropozoonoses que maior inte resse e importāncia tem despertado, desde sua descoberta. Cau sa grandes aprecnsões a hunanidade, em face da sua evolução quase sempre fatal $(1,16,29)$, acompanhada da dramaticidade peculiar dos casos da doença, especialmente em humanos ${ }^{(31)}$.

Conhecida desde a mais remota antiguidade, a sua persistência na natureza está assegurada pela capacidade - do seu agente causal de parasitar um número elevado de espécies ae vertebrados, aliada ao equilibrio biológico que estabelece com algumas delas $(1,16,29)$. Contribui também para a sua per petuação na natureza, o mecarismo usual de transmissão por contāgio direto, principalmente pelo hábito de morder de alugu mas espécies hospedeiras $(2,16,38)$, associado a excreção do vîrus através a saliva $(10,32,39,40,43)$.

A importância da saliva cono material virulento, tem sido exaustivamente demonstrada $(9,10,31,32,39,40$, 43), em periodos pré-clinnicos $(39,40), \operatorname{clinicos}(9,32,39,40$, 41), pós-clinicos, em casos de recuperação espontânea $(29,31) \mathrm{e}$ a partir de portadores assintomáticos $(10,43)$, tanto na infeo ção experimental (10), como na natural(43), embora uma perió dicidade irregular tenha sido observada na demonstração do ví rus da saliva $(10,16,31,43)$.

Apesar da importância do conhecimento da condi ção infectante da saliva do animal agressor, por ocasião dá exposição do susceptỉvel, demonstrada em vārias situações (3, $9,32,38,39,40,41,43)$, com vistas ao tratamento preventi vo, o tecido do sistema nervoso central ordinariamente 13,6 , $14,16,19,20,21,23,25)$, e o tecido da gländula salıvar 
submaxilar esporadicamente $(2,7,19,26,41,42)$; continuam a ser utilızados para demonstrar a infecção, embora sō possam ser colhidos após a morte do indivỉduo $(16,42)$.

Para o diagnóstico da raiva a partir desses espẹ cimes, vários recursos desenvolvidos no passado encontram-sc aisponîveis atualmente $(3,5,11,12,14,16,20,34,44)$, mas a pesquisa de corpūsculos de Negri em impressões e esfregaços, através coloração direta, a imunofluorescência direta e a pro va biológica por inoculação intracerebral de camundongos, apre sentam certa significância prātica (5), no uso corrente. Fimbo ra, nenhum mētodo seja inteiramente satisfatōrio para atender os requisitos de precisão, rapidez, segurança do operador, custo e conveniência no contexto das diferentes situações e prioridades $(5,11,12,20)$. A esse respeito, para melhor ade quar as necessidades do diagnóstico da enfermidade, a maio ria dos laboratōrios utiliza uma combinação apropriada dos mé todos disponîveis para tal procedimento $(5,11,12,16,20,21$, 23, 27), eliminando ao náximo, a possibjlidade de erro (3).

Considerando a prova biológica como critērio de finitivo para elucidar a presença ou ausência de infecção, a pesquisa de inclusões celulares em esfregaços e impressões tem revelado uma taxa de 10 a 12 \% de falhas $(3,16,21,27)$, en quanto a imunofluorescência direta tem demonstrado uma concor dância mais perfeita com a inoculação de camundongos $(3,5,6$, $7,20,23,36,37)$, embora resultados falsos negativos ocor ram esporadicamente em ambas as técnicas $(7,15,20)$.

Mais recentemente, outros métodos foram descr $\underline{i}$ tos, para o diagnōstico da raiva "in vivo", mediante a apli cação da técnica de anticorpos fluorescentes. Dentre estes, o teste de córnea, a biōpsia de pele e o isolamento do vỉrus a partir da saliva podem ser utilizados, com este propósito, em bora um resultado negativo não afaste a possibilidade de in fecção $(20,24,41)$.

O isolamento do virus tem sido usualmente consi. derado como o método mais apropriado para o diagnóstico dá raiva (15). Com esse objetivo, vārios aninais de laboratōrio foram ensalados, especialmente o coelho, o cobaio, o camundon 
go e o hamster $(3,16)$. No Inicio das atividades de diagnóstí co e de pesquisa sobre a raiva, o coelho representou um papel importante $(3,32)$. Mais tarde, experiências demonstraram a superioridade do camundongo branco de laboratório, de 4 a 6 semanas de idade $c$ de diferentes linhagens, para isolar e dentificar o vîrus rábico, a partir de tecido do sistema ner voso central por via intracerebral $(3,16,17,19,21,44,45)$. Ultimamente, mostrou-se igualmente útil para demonstrar a in fectividade de diferentos tecidos e secreções de animais su postamente raivosos $(7,9,26,35,43)$. Apesar das vantagens do método,o inconveniente de um resultado demorado (15), espe cialmente em casos negativos (22), levou a certas modificações da técnica original de WEBSTER \& DAWSON (44), objetivando tor nar a prova mais precoce $(22,33,35)$. Com esse intuito, MARK Son et alii(22) aplicando a técnica de imunofluorescência dí reta a encéfalos de camundongos de 5 dias de idade, inocula dos com suspensão cerebral virulenta, obtiveram resultados po sitivos 3 a 4 dias após a inoculação. Achados idênticos foram observados por PILO MORON et alii(33), em camundongos de 4 a 5 dias de idade, inoculados com glándula salivar submaxilar de cão e gato, mas só demonstraram o antigeno rábico à imuno fluorescência 4 a 5 dias após a inoculação de espécimes de tê cido cerebral. MARTELL et alii(25), utilizando suspensão de tecido encefālico de cães, bovinos e morcêgo, adicionacia de Dimetil sulfóxido (DMSO), como substância difusora, obtiveram a redução de 24 horas no periodo de incubação da dóença em ca mundongos de 21 dias de idade.

Certas variáveis, podem modificar a uniformidade e a regularidade dà resposta do sistema biológico à infeç̧ão pelo vîrus rábico(45). Nesse contexto, a idade do camundongo joga um papel importante na susceptibilidade a raiva, demons trada em diferentes oportunidades $(3,4,14,16,33)$. CASALS (8), em um experimento comparativo mostrou a diferença de sus ceptibilidade existente entre o camundongo lactente e o adul to jovem para recuperação do vỉrus da raiva, a partir de sus pensões de encéfalo, demonstrando a superioridade dos animais mais jovens. Corroborando com esta assertiva, uma amostra Flu ry de alta passagem em ovo embrionado, produziu infecção fa tal em camundongos de 3 a 8 dias de idade, pela via intracere bral, mas falhou em reproduzir a docnça cm animais de 14 dias 
de idade, sob as mesmas condições experimentais(18). Algumas amostras isoladas de animais silvestres mostraram-se mais pa togênicas para caulunưngos lactentes em comparação aos aduI tos jovens $(3,16)$. Observações similares foram descritas por GOMLZ et alii(13), em seu relato sobre o isolamento do virus rábico do encéfalo de uma criança acometida da doença de ori gem silvestre, obtido somente em camundongos lactentes de ida de inferior a 24 horas. Subsequentemente, NILSSON \& SUGAY (30), demonstraram a superioridade do camundongo lactente de 3 dias de idade, para recuperar o virus rábjco de 2 espécimes de ts cido do sistema nervoso central de herbivoros domësticos, ve rificando na ocasião do diagnōstico, uma baixa mortaliciode, um longo periodo de incubação e um caso de recuperação espon tânea, achados sugestivos de bàixa concentração de vïrus nos materiais examinados.

Um estudo avaliativo da sensibilidade do camun dongo de 4 a 8 dias de idade e de 21 a 35 dias, para demons trar quantitativamente a infectividade de espécimes encefáli cas de diferentes espēcies de animais domēsticos, demonstrou a maior precisão do camundongo lactente, tanto para o diagnós tico, como para mensurar suspensões virulentas (28).

A infectividade dà saliva de animajs raivosos, era conhecida antes da descoberta da etiologia da raiva (3) .ivo entanto, o uso desse espécime para o diagnóstico da doença foi negligenciado no passado por motivos de ordem prática (16) Mas com o conhecimento da transmissão da enfermidade, diferen tes recursos diagnósticos foram desenvolvidos, visando o iso lamento e a identificação do vîrus da raiva da saliva de ani mais acometidos por esta virose $(3,16,24,32)$.

Desse modo, PAWAN et alii(32), conseguiram iso lar o vỉrus rábico da saliva de bovinos, equinos, humanos $c$ vampiros raivosos, friccionando este material sobre a superfí cie da parede abdominal de coelhos, previallente escarificada. VAUGhiN et alis $(39,40)$, detcctaram o vîrus desse espécime, de cães e gatos infectados experimentalmente, uiilizando vamun dongos adultos jovens de 4 a 6 semanas de idade, por inocula ção intracerebral. Utilizando camundongos desmamados de 21 dias de idade, CLuMER et alii(9), demonstraram a infectivida 
de da secreção salivar de 15 cães infectados naturalmente, sen do 14 na fase clinica e de um assintomático. VALLONE et alii (41) tiveram êxito nạ j.dentificação do antígeno rábico de ma terial alivar de origem humana, utilizando a técnica de imü nofluorescência direta, aplicada pela primeira vez por GOLD. WASSER \& KISSLING ${ }^{(14)}$, ao diagnóstico da raiva, evidenciandó a possibilidade de um diagnōstico prē-mortem. Empregando a mesma tëcnica, VEERARAGIIAVAN et alii(43), demonstraram o anti geno rábico na saliva de um cão aparentemente saudável, infec tado naturalmente.

A maior sensibilidade do camundongo lactente em relação ao adulto jovem, para o isolamento do vỉrus rábico da saliva de animais infectados, também tem sido demonstrada, em algumas oportunidades $(10,31,43)$, tanto na infecção experi mental (31), como na natural (43) e de animais assintomáticos $(10,43)$, em ambas condições. Nesse sentido, NILSSOH \& CÔRTES (31) demonstraram a presença do vïrus rābico em 6 amostras de saliva de um cão infectado experimentalmente com virus prove niente de morcégo, apenas em camundongos, lactentes de 2 a 7 dias de idade, tendo fracassado nas tentativas de isolamento em camundongos adultos jovens de 30 dias de idade. Sob as mos mas condiçöes experimentais, CôRTES \& NILSSON (10) obtiveram dois resultados positivos apenas em camundongos lactentes e dois somente em adultos jovens, utilizando saliva de dois cães aparentemente saudáveis, experimentalmente infectados com uma estirpe da virus rábico proveniente de morcêgo. VEERA RAGHAVAN et alii(43), relataram 14 isolamentos do vîrus em ca mundongos lactentes e somente $6 \mathrm{em}$ adultos jovens, utilizando 913 espécimes de saliva colhidas de um cão portador assintomā tico, infectado em condições naturais.

No presente estudo, pretendemos apreciar a sensi bilidade do camundongo lactente para o isolamento do virus da raiva da saliva de cães na fase clinica da doença natural,com parando os resultados obtidos com a sensibilidade do camundor go adulto jovem. 
2. MATERIAL E METODOS.

\subsection{Secreção saliva:-.}

No presente estudo foram utilizadas 42 amostras de sa liva, colhidas na fase clinica da raiva natural, de 30 cães mantidos em observação no Instituto Pasteur. e no Centro de Controle de Zoonoses de são Paulo.

\subsection{Soluções.}

2.2.1. Cloridrato de pilocarpina.

Como estimulador da secreção salivar, utiliza mos uma solução de cloridrato de pilocarpina a 18 , em água destilada.

\subsubsection{Diluente.}

No tratamento da saliva utilizou-se āgua desti lada contendo $2 \%$ de soro de equino norrial, pre viamente inativado a $56^{\circ} \mathrm{C}$ durante 30 minutos, adicionada de 1.000 a 2.000 unidades de penici Iina e de 1,25 a 2,50 miligramas de estreptomi cina por mililitro.

\subsection{Camundongos.}

- sistcma biológico empregado para o isolamento do ví rus das amostras de saliva foi representado por camun dongos suiços albinosis, lactentes de 5 a 8 dias de idá de e adultos jovens de 4 a 6 semanas de idade, distri buidos em grupos cujo tamanho variou de 8 a 12 e de 8 a 11, respectjvamente. Cada grupo de camundongos lactentes era acompanhado da respectiva mãe.

\subsection{Colheita das amostras.}

Os animais clinicamente raivosos, cram contides por imobilização dos maxilares, recebendo logo a seguir o estimulante da secreção salivar, segundo a técnica descrita por CLEMMJR et alii(9) (1970). Ouinze minutos após, a saliva era colhicla diretamente em umá pla 
ca de Petri estēril, utilizando-se algumas vezes, uma seringa como auxiliar na operação.

\subsection{Identificação do vỉrus.}

Cada amostra de saliva recolhida era imediatamente 'a dicionada de igual volume de diluente, mantida a tem peratura ambiente por duas horas e a seguir inocula da, por via intracerebral cm um grupo de camundongos lactentes na dose de $0,01 \mathrm{ml}$ e em outro de carnundon gos adultos jovens na dose de $0,03 \mathrm{ml}$ por animal. Es tes animais eram obscrvados por 21 dias, submetendo-se aos cxames especificos para a raiva (Sellers ${ }^{(34)} \mathrm{e}$ imunofluor escência direta (14), os cérebros áaqueles que apresentassem qualquer anormalidade ou que vies sem a sucumbir a partir do terceiro dia da inoçula ção. 
3. RESULTADOS.

Os resultados obtidos neste experimento, estão. expressos nas tabelas apresentadas a seguir.

A Tabela 1 expōe os resultados do isolamento do virus rábico a partir das amostras de saliva examinadas, se gundo o sistema biológico utilizado (camundongo lactente e adulto jovem). $100 \%$ de resultados positivos foram obtidos em ambos grupos etários de camundongos.

A Tabela 2 mostra os resultados da identifica ção dos corpúsculos de Negri e do antígeno rábico do encéfalo dos camundongos lactentes e adultos jovens, segundo as técni cas de Sellers e dc anticorpos fluorescentes. Estes indicado res da infeç̧ão rábica foram demonstrados em 100\% dos animais examinados por ambos os métodos empregados. Apesar dessá con cordância de resultados, uma maior riqueza de inclusões celu lares e de antigeno rābico foi regularmente observada nos es pécimes de camundongos lactentes, particularmente à técnica de anticorpos fluorescentes.

A Tabela 3 expressa a mortalidade de camundon gos verificada nos dois grupos etários utilizados no experi mento. Os resultados revelam uma elevada taxa de mortalidade nos dois lotes de camundongos, mas uma taxa ligeiramente supe rior foi observada nos grupos de camundongos lactentes $(99,74 \%)$, em relação aos adultos jovens $(96,73 \%)$.

$\Lambda$ anālise estatistica dos resultados pelo méto do do qui-quadrado, revelou um valor $x^{2}=10,292$, altamente signiflcante ao nivel de rejelção adotado de $5 \%$. 
TABELA 1

Isolamento do vỉrus rābico da saliva de cães na fase clînica da coenca, scgundo o sistema biologico uilitiado.

\begin{tabular}{|c|c|c|}
\hline $\begin{array}{c}\text { Amostr } \\
\text { No } \\
\end{array}$ & LACTENTE & ADULTO JOVEM \\
\hline $\begin{array}{l}1 \\
2 \\
3 \\
4 \\
5 \\
6 \\
7 \\
8 \\
9 \\
10 \\
11 \\
12 \\
13 \\
14 \\
15 \\
16 \\
17 \\
18 \\
19 \\
20 \\
21 \\
22 \\
23 \\
24 \\
25 \\
26 \\
27 \\
28 \\
29 \\
30 \\
31 \\
32 \\
33 \\
34 \\
35 \\
36 \\
37 \\
38 \\
39 \\
40 \\
41 \\
42\end{array}$ & $\begin{array}{l}+ \\
+ \\
+ \\
+ \\
+ \\
+ \\
+ \\
+ \\
+ \\
+ \\
+ \\
+ \\
+ \\
+ \\
+ \\
+ \\
+ \\
+ \\
+ \\
+ \\
+ \\
+ \\
+ \\
+ \\
+ \\
+ \\
+ \\
+ \\
+ \\
+ \\
+ \\
+ \\
+ \\
+ \\
+ \\
+ \\
+ \\
+ \\
+ \\
+ \\
+\end{array}$ & $\begin{array}{l}+ \\
+ \\
+ \\
+ \\
+ \\
+ \\
+ \\
+ \\
+ \\
+ \\
+ \\
+ \\
+ \\
+ \\
+ \\
+ \\
+ \\
+ \\
+ \\
+ \\
+ \\
+ \\
+ \\
+ \\
+ \\
+ \\
+ \\
+ \\
+ \\
+ \\
+ \\
+ \\
+ \\
+ \\
+ \\
+ \\
+ \\
+ \\
+ \\
+ \\
+ \\
+\end{array}$ \\
\hline Total & $42 / 42$ & $42 / 42$ \\
\hline
\end{tabular}

$(t)=$ positivo

$(-)=$ negativo 
TABELA 2

Resultados dos exames dos cérebros de camundongos lactentes e adultos jovens, inocular?os com saliva de caes raivosos, secun do a tecnica diagnóstica utilizada.

\begin{tabular}{|c|c|c|c|c|}
\hline Camundongo & \multicolumn{2}{|c|}{ LACTENTES } & ADULTOS & JOVENS \\
\hline $\begin{array}{l}\text { Amostras } \\
\text { N\& }\end{array}$ & Sellers & I.F.D. & Sellers & I.F.D. \\
\hline $\begin{array}{l}1 \\
2 \\
3 \\
4 \\
5 \\
6 \\
7 \\
8 \\
9 \\
10 \\
11 \\
12 \\
13 \\
14 \\
15 \\
16 \\
17 \\
18 \\
19 \\
20 \\
21 \\
22 \\
23 \\
24 \\
25 \\
26 \\
27 \\
28 \\
29 \\
30 \\
31 \\
32 \\
33 \\
34 \\
35 \\
36 \\
37 \\
38 \\
39 \\
40 \\
41 \\
42\end{array}$ & $\begin{array}{l}+ \\
+ \\
+ \\
+ \\
+ \\
+ \\
+ \\
+ \\
+ \\
+ \\
+ \\
+ \\
+ \\
+ \\
+ \\
+ \\
+ \\
+ \\
+ \\
+ \\
+ \\
+ \\
+ \\
+ \\
+ \\
+ \\
+ \\
+ \\
+ \\
+ \\
+ \\
+ \\
+ \\
+ \\
+ \\
+\end{array}$ & $\begin{array}{l}+ \\
+ \\
+ \\
+ \\
+ \\
+ \\
+ \\
+ \\
+ \\
+ \\
+ \\
+ \\
+ \\
+ \\
+ \\
+ \\
+ \\
+ \\
+ \\
+ \\
+ \\
+ \\
+ \\
+ \\
+ \\
+ \\
+ \\
+ \\
+ \\
+ \\
+ \\
+ \\
+ \\
+ \\
+ \\
+ \\
+ \\
+ \\
+ \\
+ \\
+ \\
+\end{array}$ & $\begin{array}{l}+ \\
+ \\
+ \\
+ \\
+ \\
+ \\
+ \\
+ \\
+ \\
+ \\
+ \\
+ \\
+ \\
+ \\
+ \\
+ \\
+ \\
+ \\
+ \\
+ \\
+ \\
+ \\
+ \\
+ \\
+ \\
+ \\
+ \\
+ \\
+ \\
+ \\
+ \\
+ \\
+ \\
+ \\
+ \\
+ \\
+ \\
+ \\
+ \\
+ \\
+ \\
+\end{array}$ & $\begin{array}{l}+ \\
+ \\
+ \\
+ \\
+ \\
+ \\
+ \\
+ \\
+ \\
+ \\
+ \\
+ \\
+ \\
+ \\
+ \\
+ \\
+ \\
+ \\
+ \\
+ \\
+ \\
+ \\
+ \\
+ \\
+ \\
+ \\
+ \\
+ \\
+ \\
+ \\
+ \\
+ \\
+ \\
+ \\
+ \\
+ \\
+ \\
+ \\
+ \\
+ \\
+ \\
+\end{array}$ \\
\hline Total & $42 / 42$ & $42 / 42$ & $42 / 42$ & $42 / 42$ \\
\hline
\end{tabular}

(t) = positivo

$(-)=$ negativo

I.F.D. = inunofluorescêncla direta 
TABELA 3

Mortalidade de camundongos inoculados com amostras de saliva de caes raj.vosos, sequndo o grupo etario.

\begin{tabular}{|c|c|c|c|c|}
\hline $\begin{array}{l}\text { Amostras } \\
\text { Ne }\end{array}$ & LACTENTE & 8 & $\begin{array}{l}\text { ADULTO } \\
\text { JOVEM }\end{array}$ & 8 \\
\hline $\begin{array}{l}1 \\
2 \\
3 \\
4 \\
5 \\
6 \\
7 \\
8 \\
9 \\
10 \\
11 \\
12 \\
13 \\
14 \\
15 \\
16 \\
17 \\
18 \\
19 \\
20 \\
21 \\
22 \\
23 \\
24 \\
25 \\
26 \\
27 \\
28 \\
29 \\
30 \\
31 \\
32 \\
33 \\
34 \\
35 \\
36 \\
37 \\
38 \\
39 \\
40 \\
41 \\
42\end{array}$ & $\begin{array}{c}9 / 9 * \\
8 / 8 \\
10 / 10 \\
8 / 8 \\
8 / 9 \\
8 / 8 \\
8 / 8 \\
9 / 9 \\
8 / 8 \\
9 / 9 \\
8 / 8 \\
8 / 8 \\
12 / 12 \\
8 / 8 \\
8 / 8 \\
10 / 10 \\
10 / 10 \\
8 / 8 \\
9 / 9 \\
12 / 12 \\
9 / 9 \\
9 / 9 \\
10 / 10 \\
12 / 12 \\
9 / 9 \\
10 / 10 \\
9 / 9 \\
10 / 10 \\
8 / 8 \\
11 / 11 \\
12 / 12 \\
10 / 10 \\
10 / 10 \\
8 / 8 \\
10 / 10 \\
8 / 8 \\
10 / 10 \\
9 / 9 \\
8 / 8 \\
11 / 11 \\
9 / 9 \\
11 / 11\end{array}$ & $\begin{array}{r}100,00 \\
100,00 \\
100,00 \\
100,00 \\
88,89 \\
100,00 \\
100,00 \\
100,00 \\
100,00 \\
100,00 \\
100,00 \\
100,00 \\
100,00 \\
100,00 \\
100,00 \\
100,00 \\
100,00 \\
100,00 \\
100,00 \\
100,00 \\
100,00 \\
100,00 \\
100,00 \\
100,00 \\
100,00 \\
100,00 \\
100,00 \\
100,00 \\
100,00 \\
100,00 \\
100,00 \\
100,00 \\
100,00 \\
100,00 \\
100,00 \\
100,00 \\
100,00 \\
100,00 \\
100,00 \\
100,00 \\
100,00 \\
100,00\end{array}$ & 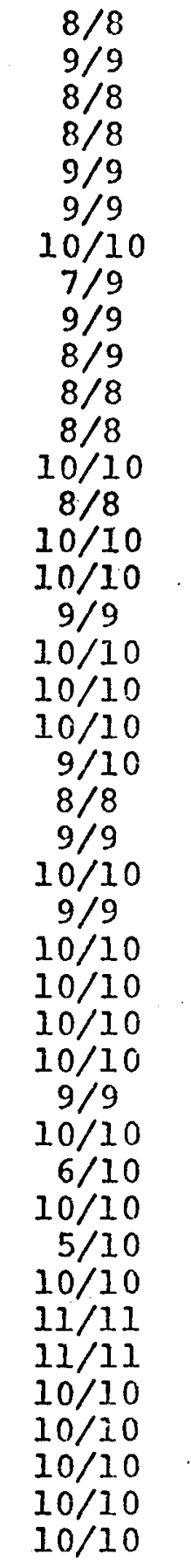 & $\begin{array}{r}100,00 \\
100,00 \\
100,00 \\
100,00 \\
100,00 \\
100,00 \\
100,00 \\
77,78 \\
100,00 \\
88,89 \\
100,00 \\
100,00 \\
100,00 \\
100,00 \\
100,00 \\
100,00 \\
100,00 \\
100,00 \\
100,00 \\
100,00 \\
90,00 \\
100,00 \\
100,00 \\
100,00 \\
100,00 \\
100,00 \\
100,00 \\
100,00 \\
100,00 \\
100,00 \\
100,00 \\
60,00 \\
100,00 \\
50,00 \\
100,00 \\
100,00 \\
100,00 \\
100,00 \\
100,00 \\
100,00 \\
100,00 \\
100,00\end{array}$ \\
\hline Total & $391 / 392$ & 99,74 & $385 / 398$ & 96,73 \\
\hline
\end{tabular}

(*) $=$ mortos/inoculados 


\section{DISCUSSÃO.}

Considerando uma resposta positiva em pelo me nos um camundongo de cada grupo inoculado, os resultados cons tantes da Tabela 1 , demonstram uma perfeita concordância en tre o camundongo lactente e o adulto jovem como substratos biológicos para o isolamento do vỉrus rábico de cães, na fase clínica da doença natural, usando como inóculo espécimes de saliva.

Resultados dessa natureza podem ser encontra dos entre sistemas biológicos que diferem ligeiramente em es pectro de sensibilidade, utilizando alta dose infectante de material virulento, como demonstraram JOHNSON \& LEACH (17) (1940), estudando a susceptibilidade de diferentes linhágens de camundongos de laboratōrio e uma variedade de campo, aó vî rus rábico, empregando como inóculo, material do sistema ner voso central de humanos e carinos.

Resultados discordantes destes, foram descri tos antes, por outros autores, embora em condições diferentes das observadas neste experimento. Desse modo, NILSSON \& COR TES $^{(31)}$ (1975), utilizando saliva de un cão infectado experí mentalmente com uma amostra isolada de morcêgo, obtiveram 6 isolamentos do vỉrus rábico em camundongos lactentes, mas fra cassaram em tal procedimento em camundongos adultos jovens.

A respeito de achados discordantes, VEERARA GHAVAN et alii(43), trabalhando com 913 amostras de saliva de um cão portador assintomātico, infectado em condições natu rais, conseguiram o isolamento do vỉrus rábico de 14 amostras em camundongos lactentes e destas, apenas 6 infectaram camun dongos adultos jovens.

Os resultados da identificação de corpúsculos de Negri e de antígeno räbico nos encéfalos de ambos grupos etarios de camundongos inoculados (Tabela 2), revelam a pre sença destes indicadores da infeç̧ão räbica em 100 a dos ant majs examinados (camundongos lactentes e adultos jovens), tan to à técnica de seliers como à imunofluorescência direta. npe 
sar dessa concordância, verificada em termos de pelo menos uma unidade positiva de cada grupo, algumas observações são suficientemente importantes, merecendo, portanto, uma análise mals po menorizada. Embora não tivéssemos estabelecido lît cri tērio quantitativo a priori, a riqueza de inclusões celulares. e de antỉgeno rábico observada nas impressões encefálicas dos camundongos foi uma constante, no entanto, mais destacada nas impressões de camundongos lactentes e mais nỉtida e regular à imunofluorescência direta.

Constatações dessa natureza foram relatadas an tes por BAGNAROLI et alii(4), para demonstrar a maior suscep tibilidade do cainundongo lactente em relação ao adulto jovem, tomando por base a quantidade de antỉgeno rābico presente no encéfalo dos camundongos inoculados com.um "pool" de material virulento de alta concentração, proveniente do sistema nervo so central de cão e de gato, segunio um critério quantitativo previamente estabelecido para calcular as diferenças signifi cativas.

Uma elevada mortalidade foi observada nos dois grupos etārios de camundongos utilizados (Tabela 3).

Realmente, os resultados revelam gue a mortalida de foi ligeiramente mais elevada nos grupos de camundongos lactentes $(99,74 \%)$, comparativamente ao mesmo evento observa do nos grupos de camundongos adultos jovens $(96,73 \%)$, eviden ciando uma ligeira diferença de resistência ao vỉrus rábico entre o camundongo lactente e o adulto jovem.

A análise estatistica dos resultados pelo método do qui-quadrado revelou um valor $x^{2}=10,292$, altamente signi ficante ao nivel de rejeição adotado de $5 \%$. 
5. CONCLUSOEES.

A anảlise dos resultados obtidos neste estudo su gere as seguintes conclusões:

- Considerando pelo menos uma unidade positiva em cada grupo de camundongo utilizado, a sensi bilidade do camundongo lactente foi idêntica a do adulto jovem, para o isolamento do virus ra bico de espécimes de saliva nas condições des te experimento.

- Houve uma ligeira superioridade do camundongo lactente para revelar inclusões celulares e an tỉgeno rábico, principalmente à prova de imu nofluorescência direta.

- A taxa de mortalidade ligeiramente mais eleva da, observada nos grupos de camundongos lacten tes, revelou à anālise estatistica uma àiferen ça altamente significante, em relação ao mesmo evento verificado nos grupos de camundongos a dultos jovens.

- A diferença do evento mor calidade verificada entre os dois sistemas estudados, mostrou uma resistência ligeiramente mais baixa nos camun dongos lactentes, em relação a dos adultos jo vens. 
6. REFERENCIAS BIBLIOGRAFICAS.

1. ACHA, P.N. Algunas consideraciones sobre las condiciones actuales de la rabia en las Americas. Salud publ. Méx., 10: $9-14,1968$.

2. AFSHAR, A. et alii. A contribution to the detection of ina pparent rabies in stray dogs. Vet. Rec., 91: 562-5, 1972.

3. ATANASIU, P. Animal inoculation and the regri body. In: BA ER, G.M., ed. The natural history of rabies. New York, Academic Press, 1975. v.l, p. 373-400.

4. BAGNAROLI, R.A. et alii. Susceptibilidad de ratones lacten tes $y$ adultos al virus rábico demonstrada por inmuno fluorescencia. Bol. Ofic. sanit. panamer., 48: 388-92, 1970.

5. BEDFORD, P.G.C.. Diagnosis of rabies in animals. Vet. Rec., 29: $160-2,1976$.

6. BEAUREGARD, M. et alii. The use of fluorescent antibody staining in the diagnosis of rabies. Can. J. comp. Med. Vet. Sc1., 29: 141-7, 1965.

7. BEAUREGARD, M. \& CASEY, G.A. Demonstration of rabies anti gen in salivary glands of rabies suspected animals.Can. J. comp. Med. , 33: 55-8, 1969.

8. CASALS, J. Influence of age factors on susceptibility of micc to rabies virus. J. exp. Med., 72: 445-51, 1940.

9. CLEMMER, D.I. et alii. Estudio sobre la rabia canina en la ciudad de Cal1. Bol. Ofic. sanit. panamer., 69: 212-20, 1970.

De acordo com: $A$ SSOCIAÇÃO PAULISTA DE BIBLIOTECARIOS.Grupo de Bibliotecārios Biomédicos. Referc̄nctas bibliográficas em ci. ências biomédicas. São Paulo, Divísao de Bibljoteca e Docu mentaçao da USP, 1971. 
10. CÔRTES, J. de A. \& NILSSON, M.R. Isolamento de vỉrus rábí co de cães aparentemente normais inoculados experimen talmente. Rev. Fac. Med. Vet. Zootec. Unit. S. Paulo. 12: $223-8,1975$.

11. DONE, J.T. et alii. Laboratory diagnosis of rabies. Vet. Rec., 99: 259, 1976.

12. EDWARDS, S.J. Laboratory diagnosis of rabies in the dog. Vet. Rec., 99: 301, 1976.

13. GOMEZ, M.R. et alii. A human case of slsunk rabies. J.Amer. med. Ass., 194: 101-3, 1965.

14. GOLDWASSER, R.A. \& KISSLING, R.E. Fluorescent antibody staining of street and fixed rabies virus antigens. Proc. Soc. exp. Biol. Med., 98: 219-23, 1958.

15. GOLDWASSER, R.A. et alii. Fluorescent antibody staining of rabies virus antigens in the salivary glands of rabid animals. Bull. Wld Hlth Org., 20: 579-88, 1959 .

16. JOHNSON, H.N. Rabies virus. In: LENNETTE, E.H. \& SCHMIDT,N. J., ed. Diagnosis procedures for viral and rickettsial diseases. 3rd ed. New York, American Health Association, 1969, p. 356-380.

17. JOHNSON, H.N. \& LEACH, C.N. Comparative susceptibility of different strains of mice to rabies virus. Amer. J. Hyg., 32: $38-45,1940$.

18. KOPROWSKI, H. Biological modification of rabies virus as a result of its adaptation to chicks and developing em bryos. Bull. Wld Hlth Org., 10: 709-24, 1954.

19. KOPROWSKI, H. Prueva de inoculation en ratones. In: ORGANI ZACION MUNDIAL DE LA SALUD. Tecnicas de laboratorio a plicadas a la rabia. Ginebra, 1956. p. 57-69. (Série de monografias, 23). 
20. LARGII, O.P. Prueva de anticuerpos fluorescentes para ra bia. Buenos Aires, Centro Panamericano de Zoonosis, 1975. 24 p. (Nota técnica, 8).

21. LEACH, C.N. Comparative methods of diagnosis of rabies in animals. Amer. J. publ. Hlth., 28: 162-6, 1938.

22. MARKSON, L.M. et alii. A biological test for rabies using suckling mice. Trop. Anim. Hlth Prod., 3: 89-92, 1971.

23. MCQUEEN, J.L. et alii. Rabies diagnosis by fluorescent an tibody. I. Its evaluation in a public health laboratory. Amer. J. publ. Hlth, 50: 1743-52, 1960.

24. MANCISIDOR, N. \& ARELLANO, C. Aislamiento de virus rábico en cultivos celulares a partir de saliva. Téc. Pec. Méx., 18: $89-92,1971$.

25. MARTELL, D.M.A. et alii. Detection de fluorescencià especi fica a rabia antes de la aparicion de signos en ratones inoculados intracerebralmente con 5 cepas de virus rábi co con $y \sin$ Dimetil-sulfoxido (DMSO). Téc. Pec. Méx., 12/13: $28-32,1969$.

26. MARTELL, D.M.A. \& ALDASORO, A. Detection de virus rābico. Bol. Ofic. sanit. panamer., 73: 117-23, 1972.

27. NIJSSSON, M.R. \& SUGAY, W. Diagnóstico da raiva - Comparą ção entre a pesquisa de inclusões em esfregaços e a ino culação de camundongos. Arg. Inst. biol., S. Paulo, 33: $11-6,1966$.

28. NILSSON, M.R. et alii. Rabies diagnosis. Comparative study on susceptibility of adult and suckling mice. Arg. Inst. biol., S. Paulo, 35: 43-7, 1968.

29. NILSSON. M.R. Revisão do concelto de que a raiva è sempre fatal. Bol. Ofic. sanit. panamer., 68: 486-94, 1970.

30. NILSSON, M.R. \& SUGAY, W. O uso de camundongos lactentes no diagnóstico da raiva. Arg. Inst. biol., S. Paulo 33: $47-8,1966$. 
31. NILSSON, M.R. \& CÔRTES, J. de A. Recuperação espontânea de um cão ralvoso experimentalmente infectado. Rev. Fac. ' Med. Vet. Zootec. Univ. S.Paulo, 12: 229-34, 1975.

32. PAWAN, J.L. et alii. Infectivity of the saliva in paraly tic rabies. Ann. trop. Med. Parasit., 31: 267-70, 1937.

33. PILO MORON, E. et alii. Diagnostic rapide de la rage par l'inoculation du cerveau et de la glande sous-maxillaire aux souriceaux et par l'immunofluorescence. Arch. Inst. Pasteur Algērie, 45: 5-10, 1967.

34. SELLERS, T.F. A new method for staining Negri bodies of rabies. Amer. J. publ. H1th, 17: 1080-1, 1927.

35. SILVA, R.A. \& SOUZA, A.M. Ocorrência do vîrus da raiva em diferentes tecidos de cão na doença natural. Pesq. Agro pec. bras., 3: 317-8, 1968.

36. SILVA, R.A. et alii. A utilização do mētodo de imunofluo rescència comparativamente com os métodos histoquimico e biológico no diagnóstico da raiva. Pesq. Agropec. bras.., Ser. Vet., 8 : 1-4, 1973.

37. SUBRAHMANYAM, B. \& PATHAK, R.C. Diagnosis of rabies in dogs - Comparative study on microscopic, biological and fluorescent antibody tests for diagnosis. Indian Vet. J.., 48: 123-7, 1971 .

38. TIERKEL, E.S. Canine rabies. In: BAER, G.M. ed. The natu ral history of rabies. New York, Academic Press, 1975, v.1, p. 123-137.

39. VAUGHN, J.B. et al11, Excretion of street rabies virus in the saliva of dogs. J. Amer. med. Ass., 193: 113-8, 1965.

40. VAUGHN, J.B. et al11. Excretion of street rabies in the sa liva of cats. J.Amer. med. Ass., 184: 119-22, 1963. 
41. VALLONe, E.F. et alii. Rabia humana. Dlagnostico "pré-mor tem" a partir de la saliva por inmunofluorescencia. Arch. Pediat. Uruguay, 37: 563-7, 1966.

42. VEERARAGHAVAN, $N$. et alii. Virus content of brains and sub maxillary glands and occurrence of Negri bodies in áni mals suspected of having died of natural rabies infec tion. Bol. Org. mund. Salud, 18: 469-71, 1958.

43. VEERARAGHAVAN, N. et alii. Studjes on the salivary excre tion of rabies virus by the dog from Surandai. Sci. Rep. Pasteur Inst. Sth. India, 1969. p. 69-70.

44. WEBSTER, L.T. \& DAWSON, J.R. Early diagnosis of rabies by mouse inoculation. Measurement of humoral immunity to rabies by mouse protection test. Proc. Soc. exp. Biol. Med., 32: 570-3, 1935 .

45. WEBSTER, L.T. A mouse test for measuring the immunizing po tency of antirabies vaccines. J. exp. Med., 70: 87-106, 1939. 